\title{
Bases de Datos sobre los Archivos y sobre el Patrimonio Documental Andaluz: BÍBARA y CENSARA
}

Con ocasión del XIV Congreso Internacional de archivos que se ha celebrado en Sevilla del 21 al 26 de septiembre, se han presentado en el stand de la Consejería de Cultura de la Junta de Andalucía dos bases de datos, elaboradas por Facultativos del Archivo General de Andalucía. Dichas bases de datos, bautizadas con los nombres de BÍBARA y de CENSARA, nos van a facilitar un conocimiento actualizado de nuestros archivos y del Patrimonio documental andaluz.

BÍBARA que recoge la bibliografía archivística andaluza, desde 1978, con 1300 títulos hasta el día de la fecha, nos permite valorar la contribución de Andalucía al desarrollo de los archivos y de la Ciencia archivística a la vez que nos permite un mayor acercamiento al Patrimonio documental conservado en los archivos.

CENSARA es la base de datos que hace posible la actualización del censo de archivos del Sistema andaluz.
El censo andaluz de archivos tuvo su primera versión en una edición en papel, en 1997, y a partir de entonces se ha revisado anualmente. Esta que se ofrece corresponde a la última actualización, elevada ahora a base de datos. Hasta la fecha, Andalucía es la única Comunidad autónoma que actualiza su censo.

Los datos que en él se ofrecen (clasificación del archivo, dirección, horario, instalaciones y equipamiento, recursos humanos, fondos $y$ colecciones y tratamiento archivístico, instrumentos de descripción, editados y sin editar) no sólo nos proporcionan una radiografía de cada archivo sino que nos facilitan un diagnóstico del propio Sistema andaluz.

Mil archivos aparecen censados con una ocupación documental de $170.676 \mathrm{~m} / \mathrm{l}$. que pertenecen a 1680 fondos y colecciones documentales.

Considerando que un censo de archivos es un instrumento de información indispensable para desarrollar una buena política de archivos, su actualización anual lo convierte en un medidor de calidad de estas instituciones del Patrimonio Histórico permitiendo conocer su desarrollo o su estancamiento, su eficacia o inoperancia, sus logros y sus fallos.

Una y otra base de datos se continuaran alimentando y su información estará permanentemente disponible en la página web del Archivo General de Andalucía (http:/www.junta-andalucia.es/agaweb)

Antonia Heredia Herrera Directora Archivo General de Andalucía

\section{La Catedral de Zamora en Internet: elementos arquitectónicos y bienes muebles}

La visita a la Página Web de la Catedral de Zamora resulta muy descriptiva, ya que el visitante puede recorrer de forma virtual su interior gracias a un plano interactivo de su planta, y a esquemas de situación de los elementos más destacados como son el coro y las capillas. A través de los mismos y con un simple movimiento del ratón, podemos localizar los distintos elementos artísticos que integran cada una de las partes.

Asimismo, la página cuenta con numerosas ilustraciones tanto de los distintas obras pictóricas y escultóricas que adornan las capillas, como de los elementos que integran el coro: sillerías, ménsulas, pináculos, apoyabrazos, intercolumnios, crestería o trascoro.
La calidad de las imágenes es aceptable, dada la exhaustividad con la que son descritos los diversos elementos, aunque el fondo negro con el que se presentan todas las páginas no parece ser el más adecuado para su correcta y más clara visualización.

Comenzamos el recorrido señalando los distintos apartados que encontramos en el portal de entrada.

En primer lugar encontramos una serie de elementos dinámicos que nos dan acceso al coro, la torre, el cimborrio, el claustro y las capillas.

Más abajo, contamos con un acceso a una serie de páginas denominadas "Especiales", donde encontramos un esquema del coro alto, otro del coro bajo, un Plano de la planta interactivo y el acceso a un apartado de Historia y Situación.

EI Coro: cuenta con varios elementos: la reja gótica, la sillería y el propio coro.

Si entramos en los esquemas de los coros alto y bajo, nos encontramos con una línea de puntos, donde la situación de cada silla se encuentra debidamente señalada al pasar por su nombre, encendiéndose en el esquema una luz naranja. Haciendo click sobre él se accederá a una descripción más detallada de la misma. Siguiendo un orden cronológico, figuran en los espaldares de la sillería baja los persona- 
jes que tienen alguna relación con el Mesías, cuyos nombres se encuentran al lado del esquema según su situación de arriba a abajo y de izquierda a derecha. Accediendo a cada uno de ellos, encontramos una descripción iconográfica.

El recorrido por el coro alto sigue el mismo orden que en el bajo.

También encontramos una descripción textual y gráfica de los pináculos que coronan el coro, así como de las escalerillas y de los apoyabrazos que separan las sillerías de ambos coros.

Del mismo modo hay una selección de las ménsulas o misericordias situadas debajo de los asientos de ambas sillerías, así como un análisis descriptivo de las puertas que comunican con el trascoro, de los elementos iconográficos de sus postigos y de sus cerraduras.

Para terminar con el exhaustivo recorrido por todos los elementos del coro, cabe mencionar la selección de pequeñas figuras que aparecen en los intercolumnios góticos que separan los sitiales del coro alto, y la crestería que remata el coro a lo largo de todo el rectángulo, cuya iconografía hace alusión a fábulas, asuntos mitológicos, alegorías y escenas de las Sagradas Escrituras.

Toda la visita va acompañada de una detallada descripción estilística e iconográfica y de un amplio repertorio gráfico.

La torre de la catedral: construida en el siglo XIII posteriormente al complejo catedralicio. Se muestra la imagen de su planta, así como el acceso a los distintos niveles, una selección de fotografías exteriores e interiores, detalles de la misma y una serie de vistas panorámicas.

El cimborrio: con una descripción estilística de la cúpula y sus partes acompañada de una selección de fotografías realizadas desde diferentes puntos de vista y épocas del año.

El claustro: muestra detalles histórico-artísticos y gráficos, así como información del museo de tapices al que se accede desde el mismo claustro. Encontramos una selección gráfica de los mismos con posibilidad de ampliación para ver los detalles.
Capillas: encontramos al igual que en el coro un esquema de distribución de las mismas dentro del recinto catedralicio. En la parte superior podemos ver la Capilla lateral izquierda, la Capilla Mayor gótica en el centro y la Capilla lateral derecha.

Al lado izquierdo y derecho de las anteriores, se encuentran una serie de capillas dedicadas a San Miguel, San Nicolás, San Bernardo, San Juan Evangelista, San Pablo, Santa Inés y San Ildefonso. Finalmente, la Sala Capitular.

La situación de cada capilla se encuentra debidamente señalada al pasar por su nombre, encendiéndose en el esquema una luz naranja. Todas ellas tienen un enlace a través del cual se accede a una información más pormenorizada, acompañada de un gran número de imágenes de los bienes que contienen: retablos, tablas pictóricas, lienzos, escudos, figuras, decoración en relieve de los arcos, sepulcros, rejas, estatuas, etc; todo ello con explicaciones detalladas de los distintos elementos y con un análisis iconográfico pormenorizado, como es el caso del gran cuadro dedicado al cardenal Mella de la Sala Capitular.

Después del detallado repaso a cada uno de los elementos analizados en esta web, cabe destacar un complemento indispensable para el completo recorrido y ubicación de cada uno de los elementos dentro de la catedral.

Se trata del Plano de la planta interactivo: donde cada parte del recinto se encuentra

\section{FICHA DE LA WEB}

URL PRINCIPAL

TITULAR

http://members.es.tripod.de/ACATEDRAL/catedral.htm
Para terminar, cabe destacar una sección dedicada a enlaces con otras sedes web relacionadas (una recopilación de museos y exposiciones de las Edades del Hombre, una selección de catedrales de Castilla y León con fotos, una exposición en la Catedral de Valencia y una página de la Iglesia de San Pedro de la Nave), y una sección de Contacto para indicar que algunos aspectos siguen todavía en construcción, y donde se aceptan también aportaciones para incluir nuevos contenidos.

Susana Limón Rodríguez Centro de Documentación del IAPH

situada e identificada en el plano por un número. Haciendo clik en el mismo, accedeEsto nos ayuda a entender el conjunto en su globalidad espacial e histórico-artística.

También encontramos una reseña de la Historia y Situación de la catedral dentro de la ciudad de Zamora, que nos habla sobre el ria de la construcción del conjunto arquitectónico y la descripción de su situación dentro de la ciudad, acompañada con un plano de la misma.

Centro de Documentación deIAPH 